\title{
Different 4TI Cells Migration under Caesalpinia sappan L. and Ficus septica Burm.f Ethanolic Extracts
}

\author{
Sari Haryanti ${ }^{1}$, Retno Murwanti ${ }^{2}$, Herwandhani Putri $^{3}$, Gagas Pradani Nur Ilmawati ${ }^{3}$, \\ Suwijiyo Pramono ${ }^{4}$, Edy Meiyanto ${ }^{3,5 *}$ \\ ${ }^{1}$ Balai Besar Penelitian dan Pengembangan Tanaman Obat dan Obat Tradisional, Kementerian Kesehatan RI, Tawangmangu \\ ${ }^{2}$ Departement of Pharmacology and Toxycology, Faculty of Pharmacy, UGM, Yogyakarta \\ ${ }^{3}$ Cancer Chemoprevention Research Center (CCRC), Faculty of Pharmacy, UGM, Yogyakarta \\ ${ }^{4}$ Departement of Pharmaceutical Biology, Faculty of Pharmacy, UGM, Yogyakarta \\ ${ }^{5}$ Departement of Pharmaceutical Chemistry, Faculty of Pharmacy, UGM, Yogyakarta
}

\begin{abstract}
Secang (C. sappan L.) and awar (F. septica Burm.f) are known of Indonesian traditional medicine that highly consumed throughout centuries in order to cure various diseases. Recently, researchers also concern about its effects as anti-cancer on various cell types. This study was conducted to understand the ethanolic extract of C. sappan L. (ECS) and F. septica Burm.f (EFS) effects on 4TI cells migration at various concentrations. Firstly, we examine cell proliferation profile with MTT assay under treatment with the extracts and obtained the IC 50 value of ECS $(20 \mu \mathrm{g} / \mathrm{mL})$ and EFS $(I 5 \mu \mathrm{g} / \mathrm{mL})$. Subsequent assay conducted was to examine the cells migration under low concentration resulting in the migration inhibitory effect of both EFS and ECS with different intensity. EFS performed better migration inhibitory effect than ECS. Finally, we conducted gelatin zymography and western blot and revealed that the migration inhibitory effect of EFS may correlate to the lowering of protein expression of MMP9 and Rac-I after 24 hours of treatment. We conclude that both extracts are potential to be developed as anticancer agent and EFS is more potent for anti-metastasis.
\end{abstract}

Keywords: C. sappan L., F. septica Burm.f, 4TI, anti-migration

\section{INTRODUCTION}

Breast cancer is the most happening evidence in the world and contributes highly in mortality index of human over the world due to its malignancy (Torre, et al., 2015). Hence, the secondary malignancy could be overcome by the administration of chemotherapeutic agents such as doxorubicin (Dong and Chen, 2014), cisplatin (Ng, et al., 2010) and busulfan-siklofosfamid (Majhail, et al., 2011). However, inappropriate treatment of chemotherapeutic agent, such as doxorubicin induces resistance of cancer cells as well as cells migration (Bandyopadhyay, et al., 2010). Therefore, various strategies should be continuously developed to inhibit its ability on migration activity.

Indonesia has ethnobotanically copious medicines from its natural sources, such as secang (Caesalpinia sappan L.) known as sappan wood and awar-awar (Ficus septica Burm.f). Sappan wood is one of the most consumed frequently as a medicine as well as healthy drink (Nirmal, et al., 2015). It is also widely used in South East Asia for various usages (Dapson and Bain, 2015). Sappan wood is known for its antioxidant (Mu'nisa, et al., 2016), antibacterial, antifungal, anti-inflammatory, and antitumour activities (Mekala and Radha, 2015). These activities were performed due to its secondary metabolite compounds such as sappanone A (Chang, et al., 2012), brazilin (Luna-Vázquez, et al., 2013), and brazilein (Senthilkumar, et al., 2011). Meanwhile, awar-awar leaves contained tylophorine, a phenanthroindolizidine alkaloid with cytotoxic activity (Wu, et al., 2002).

Its robust composition of secondary metabolites could be an opportunity to find new cochemotherapeutic agents. Several informations about its cytotoxic activities were already documented. Study in the effect of $F$. septica ethanolic extract with concentration of $6 \mu \mathrm{g} / \mathrm{mL}$ could induce MCF7 cells into apoptosis through downregulation of $\mathrm{BCl} 2$ (Sekti, et al., 2010). Hung, et al. (2014) reported that apoptosis in HeLa cell could be induced by methanolic extract of $C$. sappan with $\mathrm{IC}_{50}$ value of $26.50 \mu \mathrm{g} / \mathrm{mL}$.

*Corresponding author e-mail: meiyan_e@ugm.ac.id 
In some cases, molecular mechanism mediating cytotoxicity effect possibly correlates to the molecular events in cells migration and metastasis as well. However, these plants information about its activity in inhibiting cell migration is still lacking.

This research, therefore, is to explore $F$. septica and $C$. sappan effect on cancer malignancy using 4T1 cells model. Moreover, due to the complexity of their active compounds composition, we also study their ability to inhibit cancer cells migration solely to select the better candidate in inhibiting cancer cells migration. The purpose of this research is to develop the plant potential (F. Septica and $C$. Sappan) as anti cancer fitomedicin that can be applied further together with chemotherapeutic agents, especially in metastatic cancer.

\section{MATERIAL AND METHODS}

\section{Cell Culture}

Breast cancer cell line culture type 4T1 (originally from ATCC ${ }^{\mathrm{R}}$-CRL-2539 ${ }^{\mathrm{TM}}$ ) was obtained from Prof. Masashi Kawaichi (Nara Institute of Science and Technology, NAIST, Japan). The cells were maintained in Dulbecco's Modifies Eagles medium (DMEM) high glucose (Sigma) supplemented with 10\% FBS (Sigma), HEPES, sodium bicarbonate, $1.5 \%$ Penicilin-Streptomycin and $0.5 \%$ Fungizone (Gibco). Cells were cultured with $5 \% \mathrm{CO}$ in $37^{\circ} \mathrm{C}$.

\section{C. sappan L. (ECS) and F. septica Burm.f (EFS) Sample Preparation}

Sappan wood and awar-awar leaves were obtained from Medicinal Plant and Traditional Medicine Reseach and Development Center, Tawangmangu, Central Java, Indonesia. They were sliced, dried in oven $40^{\circ} \mathrm{C}$, pulverized, and extracted with ethanol $96 \%$ by maceration method for $3 \times 24$ hours. The macerat was filtered and dried in oven $40^{\circ} \mathrm{C}$. The dried extract and doxorubicin was dissolved in DMSO (Sigma), and freshly diluted in culture medium in several concentration before used.

\section{Cytotoxic MTT assay}

Approximately $1 \times 10^{4} 4 \mathrm{~T} 1$ cells/well were seeded in 96-well plates and incubated for 24 hours. Cells were treated with increasing concentration of ECS $(5,10,15,20,30$, and $40 \mu \mathrm{g} / \mathrm{mL})$ and EFS extract $(0.05,0.125,0.25,0.5,5,50$, and $100 \mu \mathrm{g} / \mathrm{mL})$ for 24 hours. Cultured medium was removed and cells were washed with PBS (Sigma). MTT 0.5 $\mathrm{mg} / \mathrm{mL}$ in medium were added into each well and incubated for 3-4 hours. MTT reaction was stopped by the addition of SDS $10 \%$ in $\mathrm{HCl} 0.01 \mathrm{~N}$, and incubated overnight in the dark room. The absorbance was measured using ELISA reader at $\lambda$ $595 \mathrm{~nm}$ (Biorad). Each treatment were carried out in triplicate, and the absorbance data were provided as percent viability compared to control cells (untreated).

\section{Wound Healing Assay}

4T1 cell line was cultured with $7.5 \times 10^{4}$ cell/500 $\mu \mathrm{L}$ density in well plate and incubated for 24 hours at $37^{\circ} \mathrm{C}$ until reaching percent confluence of $80 \%$. Cultured cell were washed with PBS and added culture media containing $0.5 \%$ FBS for then being incubated for 24 hours. Scratch was done in the bottom center of the well within cell layer using cell scratcher. Residue cell in the well plate were washed using culture media and treated with various concentration ECS and EFS. The culture then incubated for 48 hours at $37^{\circ} \mathrm{C}$ and documented under inverted microscope against cell migration rapidity after $0,18,24$ and 42 hours.

\section{Quantification of Wound Healing Assay}

The space from scratch treatment between control and treatment culture cell at various time incubation was quantified using ImageJ software and defined as cell migration area. Percent closure was further analyzed using ANOVA statistic analysis with $95 \%$ percent reliance.

\section{Western Blot}

Approximately $10^{6} 4 \mathrm{~T} 1$ cells were seeded in $10 \mathrm{~cm}$ tissue culture dish, and incubated for 24 hours. Cell were treated with ECS $10 \mu \mathrm{g} / \mathrm{mL}$, EFS extract $2 \mu \mathrm{g} / \mathrm{mL}$, or doxorubicin $0.4 \mu \mathrm{M}$ for 24 hours. Protein was extracted using Pro-prep (Intron Biotechnology), then separated in $14 \%$ acrylamide gel by SDS-PAGE electrophoresis. After transferring to polyvinylidene fluoride (PVDF) membrane, the membrane was incubated overnight at $4^{\circ} \mathrm{C}$ with either the mouse monoclonal antibody against Rac1 (Santa Cruz cs22475) or $\beta$-actin (Santa Cruz sc47778). After incubation with secondary antibody anti-mouse (Santa Cruz sc-516102) for 1 hour, the protein bands were visualized using ECL 
(Amersham) and detected using Luminograph. The relative protein levels were calculated in reference to the amount of $\beta$-actin protein.

\section{RESULTS}

\section{The effect of ECS and EFS in cells proliferation}

To understand the potential effect of ethanolic extract $F$. septica (EFS) and C. sappan (ECS) in inhibiting cells migration, firstly we measured the cytotoxicity effect of both extracts to the tested cells, 4T1. The result showed that both extracts decreased cells viability in dose dependent manners with $\mathrm{IC}_{50}$ values of $20 \mu \mathrm{g} / \mathrm{mL}$ for ECS, and $15 \mu \mathrm{g} / \mathrm{mL}$ for EFS. These $\mathrm{IC}_{50}$ values seems not significantly different but exhibited a charracteristic effect in each treatment in viability profiles as seen in morphology changes (Fig. 1). The $\mathrm{IC}_{50}$ values then used as standard concentration for wound healing migration assay by which the concentration should not affect the cells viability significantly.

\section{The effect of ECS and EFS in cells migration}

Migration of 4T1 cell cultures were analyzed by scratching the cell culture and observed periodically up to 48 hours. In this study, we use low concentration of ECS and EFS to give different migration effect to the 4T1 cell culture. Low concentration of ECS 5 and $10 \mu \mathrm{g} / \mathrm{mL}$ restrict cell migration $71.7 \%$ and $42.4 \%$ respectively compared to untreated cells (99.1\%) within 48 hours. Whereas, low concentration of EFS 1.25 and $2.5 \mu \mathrm{g} / \mathrm{mL}$ could inhibit cell migration $23.5 \%$ and $22.1 \%$ respectively. Compared to ECS, we believe that EFS more effective to inhibit cell migration.

A
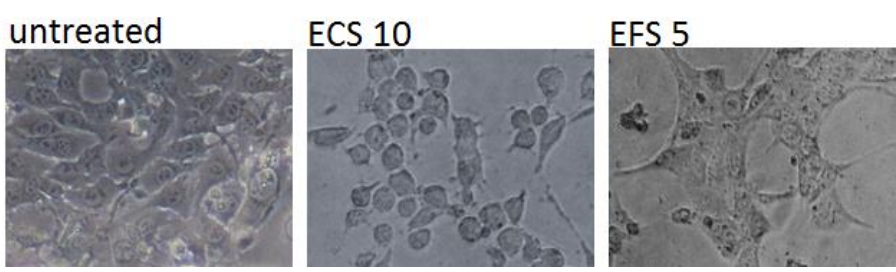

B

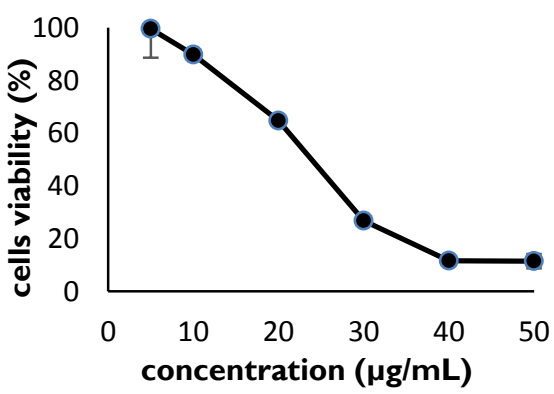

C 100

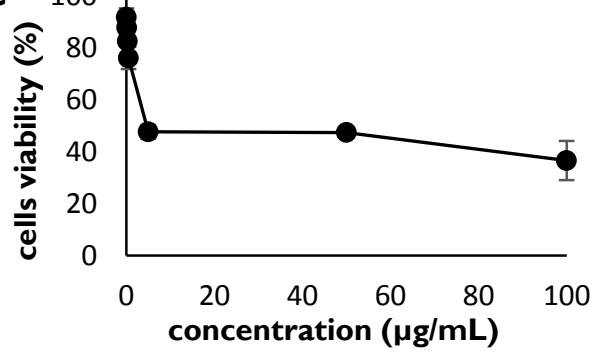

Figure I. Cytotoxicity of ECS and EFS on 4TI cell after 24 hour. Cytotoxicity was analyzed using series concentration and measured by ELISA reader after treated with MTT reagent. (A) Morphology changes of 4TI cells after treated with ECS and EFS. (B) IC 50 of ECS were calculated and had given value of $12 \mu g / \mathrm{mL}$. (C) EFS have IC 50 value of 15 $\mu \mathrm{g} / \mathrm{mL}$. 


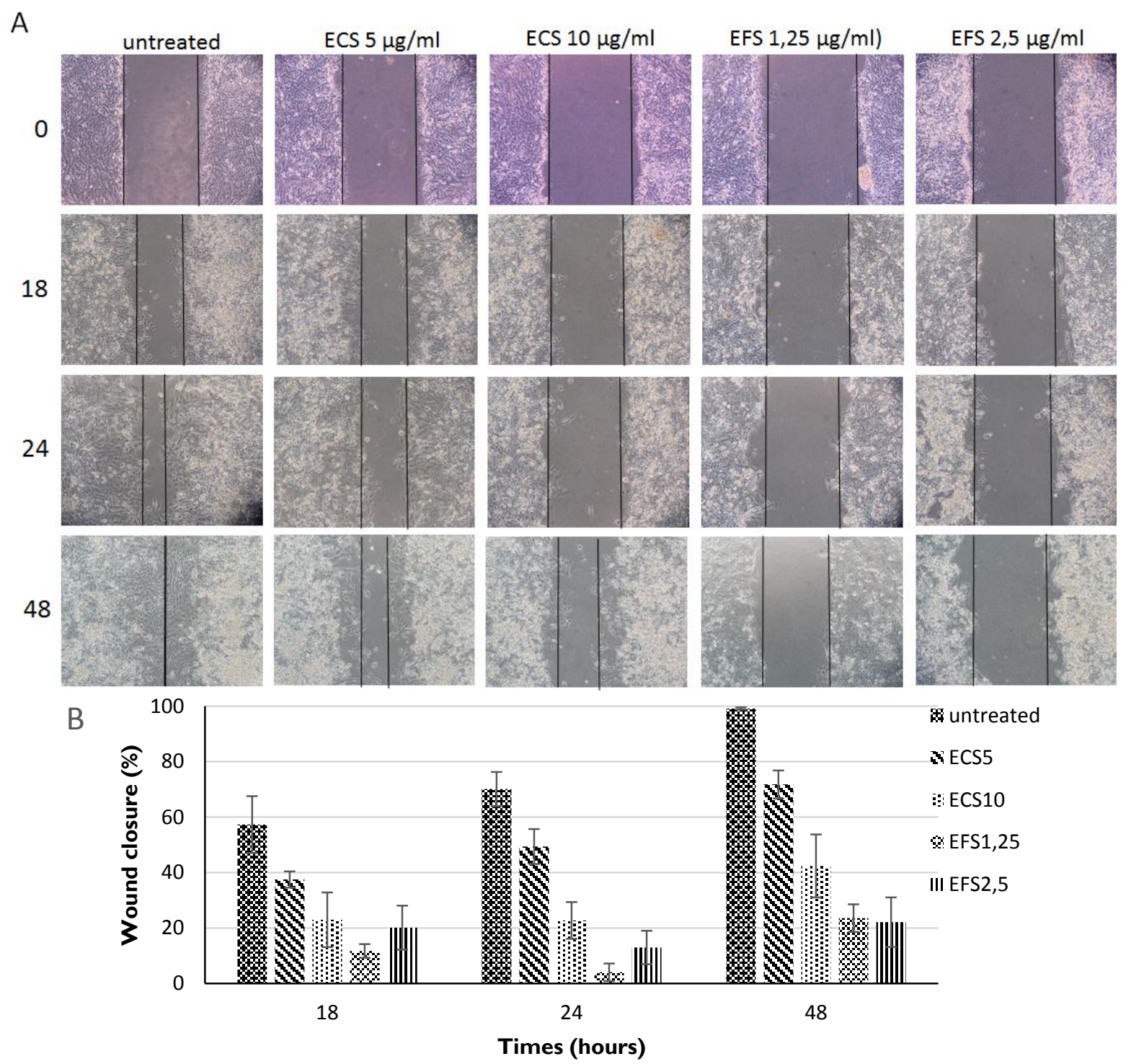

Figure 2. Migration effect of ECS and EFS on 4TI cells. Cell culture morphology after scratch and treated with ECS 5 and $10 \mu \mathrm{g} / \mathrm{mL}$ and EFS 1.25 and $2.5 \mu \mathrm{g} / \mathrm{mL}$ for 48 hours under 100X magnification (A). Graphic B showed quantification of wound closure by imageJ software, performed in triplicate, and represented as mean \pm SD.

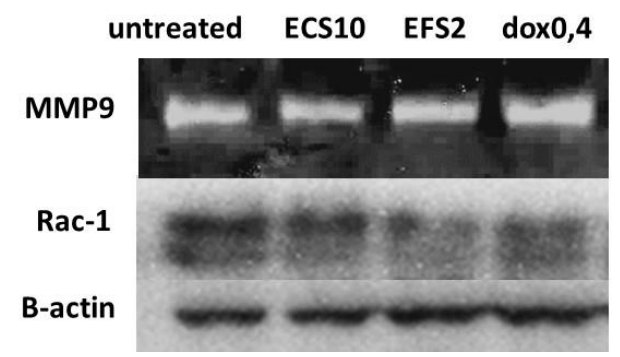

Figure 3. Protein Expression in 4TI cell after treatment with ECS and EFS. Expression was compared between control (untreated), ECS, and EFS treatment. Gelatin Zymography showed the MMP9 expression were observed differently among the treatment condition after 24 hour treatment. Racl expression was observed with western blot shown different expression between groups. The levels of Expression were normalized by comparing with $\beta$ actin expression level and doxorubicin treatment as a positive control. 
Activity of MMP9 protein that representing its expression level performed different result under different treatment. ECS treatment $(10 \mu \mathrm{g} / \mathrm{mL})$ induces cell to restain MMP9 production compared to the control cell. Treatment with EFS $(2 \mu \mathrm{g} / \mathrm{mL})$ also gave similar MMP9 expression with ECS treatment. Here we include doxorubicin treatment $\left(\mathrm{IC}_{50}\right.$ concentration) as a comparison of up-regulated expression of MMP9 and gave migration inhibitory effect to the cells. Cells migration also occured as a consequence of Rac-1 protein expression. Treatment with ECS give similar expression compared with the control. Lowest Rac1 expression was obtained from EFS treatment. This phenomenon represent that EFS could obstruct cell migration in relation with Rac-1 expression.

\section{DISCUSSION}

Cancer cells migration is the critical step of cancer metastasis that chalange to be solved. The main purpose of this research is to find the most potential metastasis-inhibitor to be developed as anti-cancer agent. In this study we demonstrated that ECS and EFS are relatively active as cytotoxic agent towards $4 \mathrm{~T} 1$ cells with seems to be similar $\mathrm{IC}_{50}$. By having this $\mathrm{IC}_{50}$ value, both extracts have a relatively strong cytotoxic effect and could be further explored as an anti-cancer agent. Effect of sappan wood extract on $\mathrm{HeLa}$ cell give $\mathrm{IC}_{50}$ value on $26.50 \mathrm{ug} / \mathrm{mL}$ (Hung, et al., 2014). Another study of C. sappan ethanolic extract give IC50 value of $37 \mathrm{ug} / \mathrm{mL}$ on MCF-7 cells (Khamsita, et al., 2012) and $25 \mathrm{uM} / \mathrm{mL}$ on MCF7/HER2 cells (Rahmawaty, et al., 2016). Meanwhile, F. septica ethanolic extract on T47D cells giving $\mathrm{IC}_{50}$ of $13 \mathrm{ug} / \mathrm{mL}$ (Fitriasari, et al., 2011) and $48 \mathrm{ug} / \mathrm{mL}$ on MCF-7/HER2 (Sutejo, et al., 2016). Compared with previous study, our experiment on 4T1 cells give another perspective about the inhibitory effect of $C$. sappan and $F$. septica extracts on metastatic cells.

Since the cytotoxic effect of both extracts are relatively strong, we use lower concentration to investigate the migration effect. Interestingly, both extract gave different effect on cell migration. In our experiment, EFS looked better in inhibiring cells migration than ECS. This phenomenon possibly occured due to its different active compound such as Brazilein and Brazilin (phenolic compounds) in $C$. sappan and tylophorine (alkaloid) in F. septica
Burm.f Tylophorine, isolated from Tylophora indica, was revealed could inhibit angiogenesis via vascular endhotelial growth factor receptor 2 (VEGFR2) signaling pathway (Saraswati, et al., 2013). Our data give insign for further investigation to gain the detail information about this effect.

Since migration is a physiological process of cells mediated by some molecular signaling events, then we identify status of Rac-1, a protein that plays an importand role in early stage of migration (Katoh, et al., 2006). Interistingly, EFS sligthly suppressed the level of Rac-1, but not ECS. Even there are some possibilities of molecular changes in the down regulation of migration, but this data suggest that the lowering expression of Rac-1 may contribute significantly to the decreasing of the cells migration. Moreover, EFS also exerts lowering MMP-9 expression, thus there will be contribute to the inhibition of cells metastasis. Hereby, we suggest that EFS has strong potential as an anti-metastasis agent compared to ECS. Further Study should be done to explore more deeply the potency of EFS to overcome the migration effect of doxorubicin as well as cisplatin in higly metastatic cancer cells.

\section{REFERENCES}

Bandyopadhyay, A., Wang, L., Agyin, J., Tang, Y., Lin, S., Yeh, I.T., et al., 2010, Doxorubicin in Combination with a Small TGF $\beta$ Inhibitor: A Potential Novel Therapy for Metastatic Breast Cancer in Mouse Models, PLOS ONE, 5(4), el0365, doi: 10.1371/journal.pone.00I0365.

Chang, T.S., Chao, S.Y. and Ding, H.Y., 2012, Melanogenesis Inhibition by Homoisoflavavone Sappanone A from Caesalpinia sappan, Int. J. Mol. Sci., 13(8), 10359-10367.

Dapson, R. and Bain, C., 2015, Brazilwood, Sappanwood, Brazilin and the Red Dye Brazilein: From Textile Dyeing and Folk medicine to Biological Staining and Musical Instruments, Biotech. Histochem., 90(6), 40I423.

Dong, C. and Chen, L., 2014, Second Malignanciesafter Breast Cancer: The Impact of Adjuvant Therapy, Mol. Clin. Oncol., 2(3), $33 \mathrm{I}-336$. 
Fitriasari, A., Pratama, R., Ikhtiyarsah, Y., Anindyajati and Ikawati, M., 20II, Ekstrak Etanolik Daun Awar-Awar (F. septica) Secara Sinergis Meningkatkan Efektivitas Doxo Terhadap Sel Kanker Payudara T47D, JIFI J. IImu Kefarmasian Indones., 9, 67-7I.

Hung, T.M., Dang, N.H. and Dat, N.T., 2014, Methanol Extract from Vietnamese Caesalpinia sappan Induces Apoptosis in HeLa Cells, Biol. Res., 47(I), 20. doi: 10.1 |86/07| 7-6287-47-20.

Katoh, H., Hiramoto, K. and Negishi, M., 2006, Activation of Racl by RhoG Regulates Cell Migration, J. Cell Sci., I 1 9(I), 56-65.

Luna-Vázquez, F., Ibarra-Alvarado, C., Rojas-Molina, A., Rojas-Molina, I. and Zavala-Sánchez, M., 2013, Vasodilator Compounds Derived from Plants and Their Mechanisms of Action, Molecules, I8(5), 58|4-5857.

Majhail, N.S., Brazauskas, R., Rizzo, J.D., Sobecks, R.M., Wang, Z., Horowitz, M.M., et al., 20II, Secondary Solid Cancers After Allogeneic Hematopoietic Cell Transplantation Using Busulfancyclophosphamide Conditioning, Blood, I I 7(I), 316-322.

Mekala, K. and Radha, R., 2015, A Review on Sappan Wood-A Therapeutic Dye Yielding Tree, Res. J. Pharmacogn. Phytochem., 7(4), 227, doi: $10.5958 / 0975-4385.2015 .00035 .7$.

Mu'nisa, A., Muflihunna, A. and Hala, Y., 2016, Antioxidant Activity Assay of Sappan wood (Caesalpinia sappan L.), Proceeding, Int. Conf. Math. Sci. Technol. Educ. Their Appl. I.

Ng, A.K., Kenney, L.B., Gilbert, E.S. and Travis, L.B., 2010, Secondary Malignancies Across the Age Spectrum, Semin. Radiat. Oncol., 20(I), 67-78.

Nirmal, N.P., Rajput, M.S., Prasad, R.G.S.V. and Ahmad, M., 2015, Brazilin from Caesalpinia
Sappan Heartwood and Its Pharmacological Activities: A review, Asian Pac. J. Trop. Med., 8(6), 42I-430.

Saraswati, S., Kanaujia, P., Kumar, S., Kumar, K. and Alhaider, A., 2013, Tylophorine, A Phenanthraindolizidine Alkaloid Isolated from Tylophora Indica Exerts Antiangiogenic and Antitumor Activity by Targeting Vascular Endothelial Growth Factor Receptor 2mediated Angiogenesis, Mol. Cancer, I2(I), 82, doi: 10.1 I86/1476-4598-12-82.

Sekti, D.A., Mubarok, M.F., Armandani, I., Junedy, S. and Meiyanto, E., 2010, Ekstrak Etanolik Daun Awar-awar (Ficus septica Burm. f.) Memacu Apoptosis Sel Kanker Payudara MCF-7 Melalui Penekanan Ekspresi Bcl-2, Maj. Obat Tradis., 15(3), 100-104.

Senthilkumar, N., Murugesan, S., Banu, N., Supriya, S. and Rajeshkannan, C., 20II, Biochemical Estimation and Antimicrobial Activities of the Extracts of Caesalpinia Sappan Linn, Bangladesh J. Sci. Ind. Res., 46(4), 429-436.

Sutejo, I.R., Putri, H., Meiyanto, E., 2016, Synergistic Combinantion of Curcuma Xanthorrhiza, Ficus septica and Doxorubicin Inhibits Metastasis of Breast Cancer Through Inhibition MMP-9 Activity, Proceeding, UNEJ E-Proceeding S.I, PP. I37I4I.

Torre, L.A., Bray, F., Siegel, R.L., Ferlay, J., LortetTieulent, J. and Jemal, A., 2015, Global Cancer Statistics 2012, CA. Cancer J. Clin., 65(2), 87-108.

Wu, P.L., Rao, K.V., Su, C.H., Kuoh, C.S. and Wu, T.S., 2002, Phenanthroindolizidine Alkaloids and Their Cytotoxicity from the Leaves of Ficus Septica, Heterocycles, 57(I2), 240I2408. 